\title{
Analysis and Design of Sales Information System on Web-Based E-Commerce in Yoga Farm Catfish Breeding Business Using UML
}

\author{
Muhamad Ridho Dwi Cahyo, Candiwan* \\ Faculty of Economics and Business, Business Management Telecommunication and Informatics, Telkom University, \\ Bandung, Indonesia \\ Email: ${ }^{1}$ ridhodwicahyo0@ gmail.com, 2,* candiwan@telkomuniversity.ac.id \\ Email Correspondence: candiwan@telkomuniversity.ac.id
}

\begin{abstract}
Abstrak-Yoga Farm adalah Usaha Mikro, Kecil, dan Menengah (UMKM) yang berfokus pada pembibitan ikan lele yang masih melakukan proses bisnis secara manual. Dengan proses ini, informasi yang diterima oleh pihak terkait sangat sulit diperoleh dengan cepat. Karenanya, produk masih belum banyak dikenal, dan pelanggan masih sedikit karena sistem yang digunakan dalam penjualan dan promosi masih menggunakan sistem manual. Metode penelitian yang digunakan adalah kualitatif. Penelitian ini bertujuan untuk membuat sistem informasi penjualan yang direkomendasikan di Yoga Farm dan merancang menggunakan Unified modeling language (UML) untuk proses bisnis yang direkomendasikan. Pelanggan akan mendapatkan informasi produk secara real-time, produk dapat dikenali secara luas, dan jumlah pelanggan Yoga Farm dapat meningkat. Berdasarkan hasil penelitian ini, adopsi sistem informasi penjualan berbasis web tentunya dapat memudahkan dalam mendapatkan informasi terbaru dengan cepat, dapat memperluas pasar dan juga dapat memudahkan pelanggan dalam bertransaksi. Untuk penelitian yang akan datang, penelitian ini dapat dijadikan referensi untuk melakukan penelitian serupa pada UMKM lain untuk meningkatkan penjualan.
\end{abstract}

Kata Kunci: e-Commerce, Unified Modeling Language, Berbasis Web, Waterfall, Bisnis Pembibitan

Abstract-Yoga Farm is a Micro, Small, and Medium Enterprises (MSME) that focuses on catfish breeding that is still doing business processes manually. With this process, information received by related parties is very difficult to obtain quickly. Therefore, the product is still not widely known, and customers are still few because the system used in sales and promotions still uses a manual system. The research method used is qualitative. This study aims to create a sales information system recommended at Yoga Farm and design using Unified modeling language (UML) for the recommended business processes. Customers will get product information in real-time, products can be widely recognized, and the number of Yoga Farm customers can increase. Based on the results of this study, adoption of a web-based sales information system can certainly make it easier to get the latest information quickly, can expand the market and can also facilitate customers in the transaction. For future research, this research can be used as a reference for conducting similar studies at other MSMEs to increase sales.

Kata Kunci: e-Commerce, Unified Modeling Language, Web-Based, Waterfall, Breeding Business

\section{INTRODUCTION}

The rapid development of information technology at this time gives new ideas in carrying out business processes used manually into an integrated system. Besides the rapid growth of computer technology and the level of information that continues to experience significant growth, the production rate of software increases, and traditional software modeling languages will not be able to meet the demands of software development [1]. Besides that, information technology is beneficial to improve the expansion of current and future business, and communication technology is faster than ever [2]. Integrated technology or a system has become a necessity when viewed from high business competitors. One of this growth is the Internet, which allows us to exchange information widely and in real-time.

The internet is an instrument that has grown in size and scope over time [3]. The growth of the Internet in Indonesia has increased significantly, which of course, the number will continue to grow along with the development of technology, social media, besides that the internet also has a strong influence on the creation of online shopping sites [3]. which increasingly triggers people to use the Internet to get the latest information. The internet can enable small businesses to get access to information infrastructure that is larger than existing large companies. In addition, the Internet is also useful as a good tool for potential customers because they do not need to go to see the product directly, but the product will be displayed on the web so consumers can make purchases anytime and anywhere, and prospective customers can also communicate with producers through the internet [4].

Based on data obtained from the APJJI website, Internet users in Indonesia reached 143.26 million people, so it can be concluded that the enthusiasm of the Indonesian population towards the Internet is very high [5]. A large number of Internet users in Indonesia has resulted in the emergence of potential developments in electronic commerce in Indonesia. According to Junadi and Sfenrianto, the rapid development of e-commerce provides opportunities for companies to increase their income through the Internet [6]. Besides, convenience is one of the benefits that will be felt by customers from the existence of e-commerce because customers can place orders anywhere and anytime [7].

Based on the 2017 annual report of the development of the potential of Fish Resources in Indonesia, marine fishery stock reached 6.19 million tons in 1997 and went up to 12.54 million tons in 2016. It proves that the potential of fisheries in Indonesia is very perspective [8]. 
During the 2015-2018 period, the volume of Indonesian aquaculture production in that period continued to increase with an average annual increase of 3.36 percent per year. Aquaculture production in 2018, based on main commodities, showed that tilapia commodity reached 1.5 million tons, shrimp reached 1.4 million tons, catfish reached 1.3 million tons, milkfish reached 778 thousand tons, catfish reached 391 thousand tons, carp reached 382 thousand tons, carp reached 269 thousand tons, and seaweed reached 10 million tons [9].

The development of catfish in Indonesia is increasing due to catfish is one of the fisheries commodities that are currently being cultivated by the community both on a large scale and small scale households. Catfish is a commodity that is very popular by the public [10]. This is because catfish have various advantages, including fast growth, and have the ability to adapt to a high environment [11].

Micro, Small, and Medium Enterprises (MSMEs) play a role as an economic driver in the country of Indonesia. MSMEs play a major role in the development and growth of the Indonesian state. The number of MSMEs in Indonesia reaches 99.9 percent (62.9 million MSMEs and 5460 large companies) of the total business units in Indonesia [12]. Yoga Farm is a Micro, Small, and Medium Enterprises (SMEs) that focuses on catfish breeding, and all business process activities are still carried out in the traditional way. In 2019, Yoga Farm's revenue tends to fluctuate because the number of customers is still small, the product is unknown, and sales transactions are still carried out offline so that customer buying interest decreases. By utilizing e-commerce companies can increase revenue, increase the number of customers, market expansion, means of promotion, opportunities for opening new businesses, ease of relationships with customers, and customer satisfaction [13]. Besides, E-commerce can be used as an alternative source of competitive advantage because it is able to provide the best and fastest service for its customers [13].

This study aims to make recommendations for improving a web-based e-commerce sales system in Yoga Farm using UML modeling consisting of Use Case Diagrams, Case Scenarios, Activity Diagrams, Sequence Diagrams, and Class Diagrams. Through this website information system, it is expected to increase the need for data and information for Yoga Farm potential customers, in which the potential customers can exchange data and information with transactions on products available in Yoga Farm.

\section{RESEARCH METHODOLOGY}

\subsection{Sales}

Sales is known as an activity carried out by a person in selling goods or products owned by both goods or services to the market to achieve a desired goal [14].

\subsection{Direct Sales Via The Website}

Direct sales via the website. It is an effort to reduce transaction costs by reducing distributors in distribution channels [15] so that the income obtained will certainly be higher.

\subsection{E-Commerce}

E-commerce is a business activity that uses the Internet and websites as a medium for transactions. Broadly speaking, e-commerce is a transaction activity that uses a digital or online system to make the process of purchasing products or services carried out between individuals and organizations. As stated E-commerce is a technology that becomes an important requirement for organizations engaged in trade [16]. Besides that, e-commerce is also a necessity of a business that has advanced in developing its business because it has many benefits. First, costumers do not need to come directly to the location to make purchases, while companies can carry out transaction activities in 24 hours. Second, in terms of finances, costumers can cut costs that will be incurred while entrepreneurs can save promotional costs. Third, if the store location is far, costumers can save on travel costs by reimbursing shipping costs that are much cheaper while entrepreneurs can market their stores to the wider area [17].

\subsection{UML (Unified Modeling Language)}

Unified Modeling Language is a standard specification language used to document, specify and build software [18]. Besides, UML is able to represent the design of information systems that will be made so that it becomes an information system that is ready for use by users [19].

\subsection{UI (User Interface)}

User Interface is an important part of a system or application [20]. It is a way for programs and users to interact with each other. Besides, UI is part of a system that plays a role in the occurrence of direct interaction from the user. Therefore, the design of the UI is one important point that influences [21].

\subsection{Waterfall}


JURNAL MEDIA INFORMATIKA BUDIDARMA

Volume 4, Nomor 3, Juli 2020, Page 683-692

ISSN 2614-5278 (media cetak), ISSN 2548-8368 (media online)

Available Online at https://ejurnal.stmik-budidarma.ac.id/index.php/mib

DOI 10.30865/mib.v4i3.2106

The principle of the waterfall model is an example of a plan-based process, in which, in carrying out its operations, it must first do a planning and scheduling of all process activities before starting to work on it[22]. Here is an illustration of waterfall modeling [22].

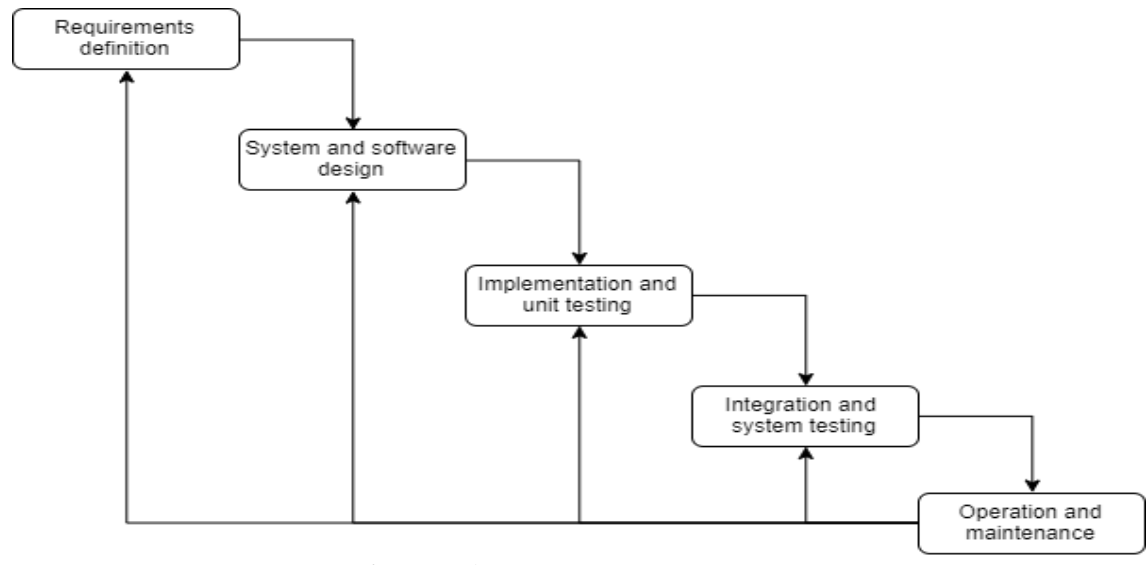

Picture 1. Waterfall Model

\section{RESULT AND DISCUSSION}

In this section, there are two stages carried out, namely analyzing the ongoing business processes and designing the proposed information system. The Unified Modeling Language is used to explain the stages of a business process in a recommended system.

\subsection{Analyzing The Running Business Processes}

Based on the results of interviews and observations, it is known that the business processes running in Yoga Farm still have some shortcomings, one of which is the manual system in Yoga Farm, so the process of recording sales records and recording inventory products is still done manually using a notebook. In the sales system, it is also still done manually by accepting orders via telephone or SMS and also face-to-face between the seller and the buyer.

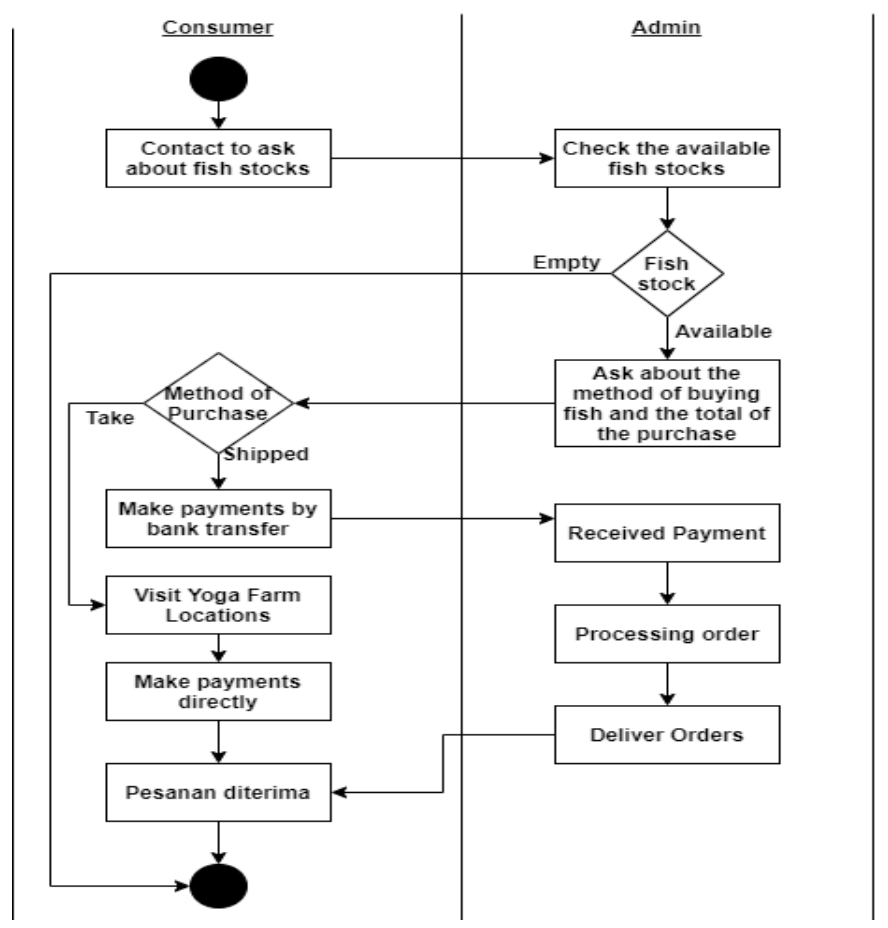

Picture 2. Yoga Farm business process

Evaluation of the current system aims to find out the weaknesses or deficiencies of the system in order to be fixed. From the description of the system analysis currently running in Yoga Farm, it can be concluded that there are some shortcomings or weaknesses in the running system. The weaknesses or problems and solutions are listed in table 1. 
Table 1. System evaluation is running

\begin{tabular}{|c|c|c|}
\hline No & Problem & Solution \\
\hline 1 & The absence of a good promotion system & $\begin{array}{l}\text { The web-based sales application system can be used as a } \\
\text { good promotional media. }\end{array}$ \\
\hline 2 & Sales transaction system is still done offline & $\begin{array}{l}\text { By using the web-based sales application system, sales } \\
\text { transactions can be done anywhere and anytime by the } \\
\text { customer as well. }\end{array}$ \\
\hline 3 & $\begin{array}{l}\text { Processing of sales and inventory data still } \\
\text { uses an accounting system }\end{array}$ & $\begin{array}{l}\text { By using the web-based application system, the } \\
\text { recording of sales and inventory data will be stored } \\
\text { properly. }\end{array}$ \\
\hline 4 & $\begin{array}{l}\text { The process of making reports and storing } \\
\text { data is not well organized. }\end{array}$ & $\begin{array}{l}\text { By using a web-based sales application system, making } \\
\text { reports and data storage can be more effective. }\end{array}$ \\
\hline 5 & $\begin{array}{l}\text { There is no a good sales media that is used to } \\
\text { provide information about the existence of } \\
\text { Yoga Farm }\end{array}$ & $\begin{array}{l}\text { Web-based sales application system can be a more } \\
\text { effective marketing medium. }\end{array}$ \\
\hline
\end{tabular}

\subsection{Design As A Proposed Information System}

Based on the results of the analysis of the system running on Yoga Farm, it can be seen that the old system is still manual, so it cannot meet the needs of processing data quickly and effectively. The proposed system is expected to be able to provide a clear picture in the making of an information system that can help the sales process and expand the costumers of Yoga Farm with UML (Unified Modeling Language) diagrams. In this study, we use just three diagrams: the Use Case Diagram, Class Diagram, and Sequence diagram.

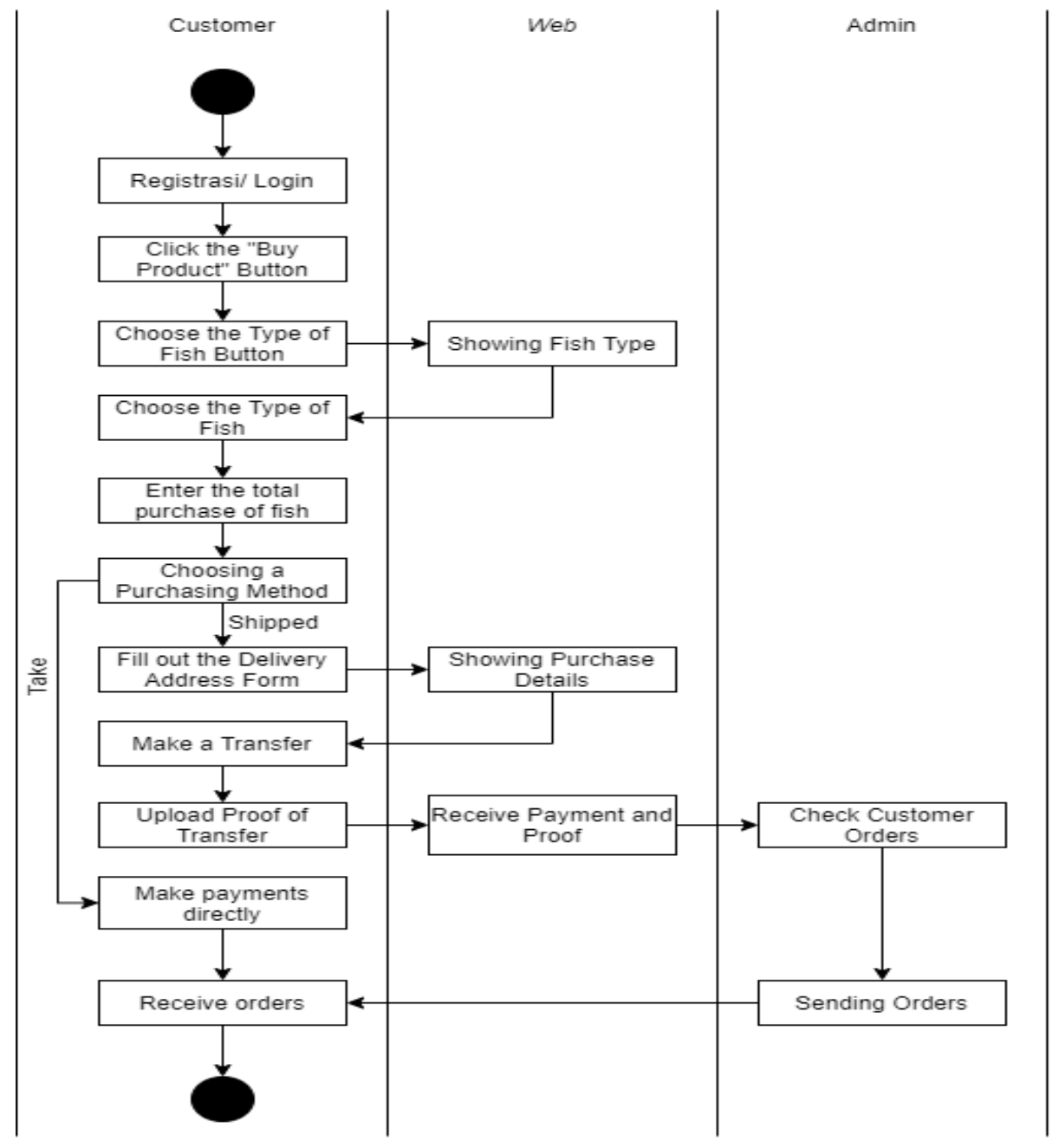

Picture 3. Proposed Sales Information System Procedure

Picture 3 explains the sales information system procedure recommended for Yoga Farm. The recommended sales information system can provide product-related information quickly to the buyers, so that they will become satisfied and comfortable in shopping. 
ISSN 2614-5278 (media cetak), ISSN 2548-8368 (media online)

Available Online at https://ejurnal.stmik-budidarma.ac.id/index.php/mib

DOI 10.30865/mib.v4i3.2106

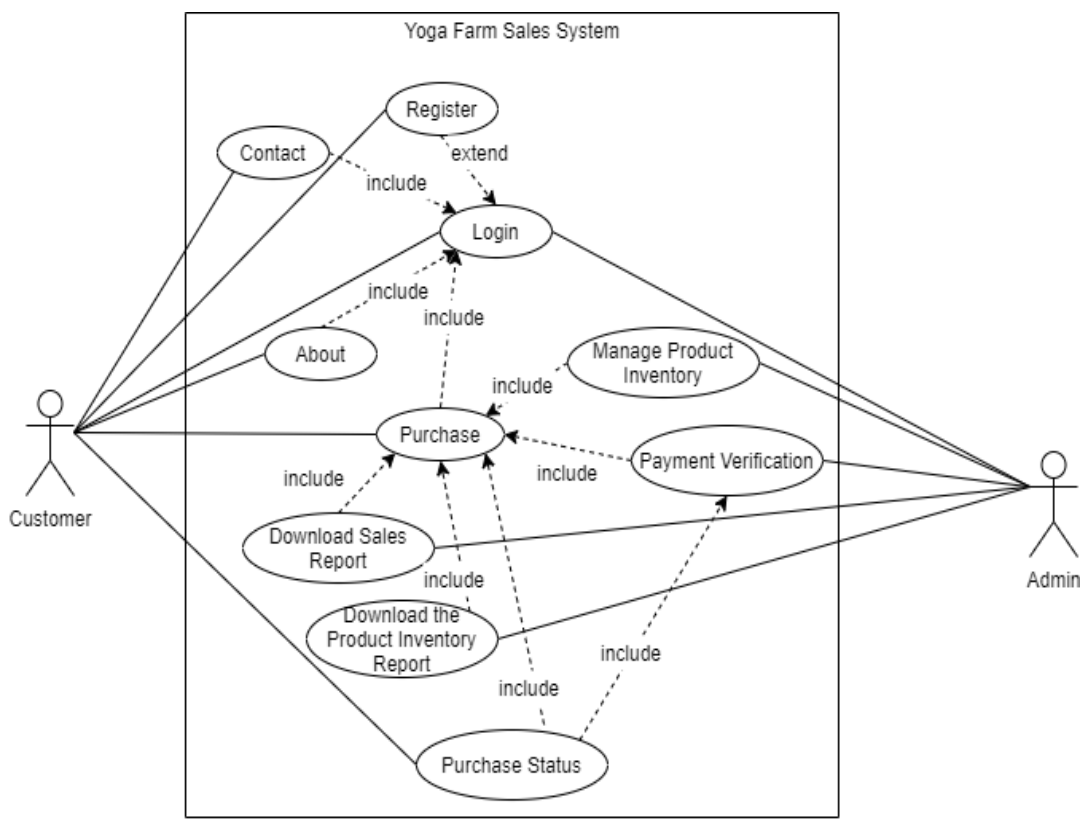

Picture 4. Proposed Sales Information System Procedure

Figure 4 explains the relationship between the user and the system. It is also known that there are 2 actors involved or connected to the system, namely customer and admin.

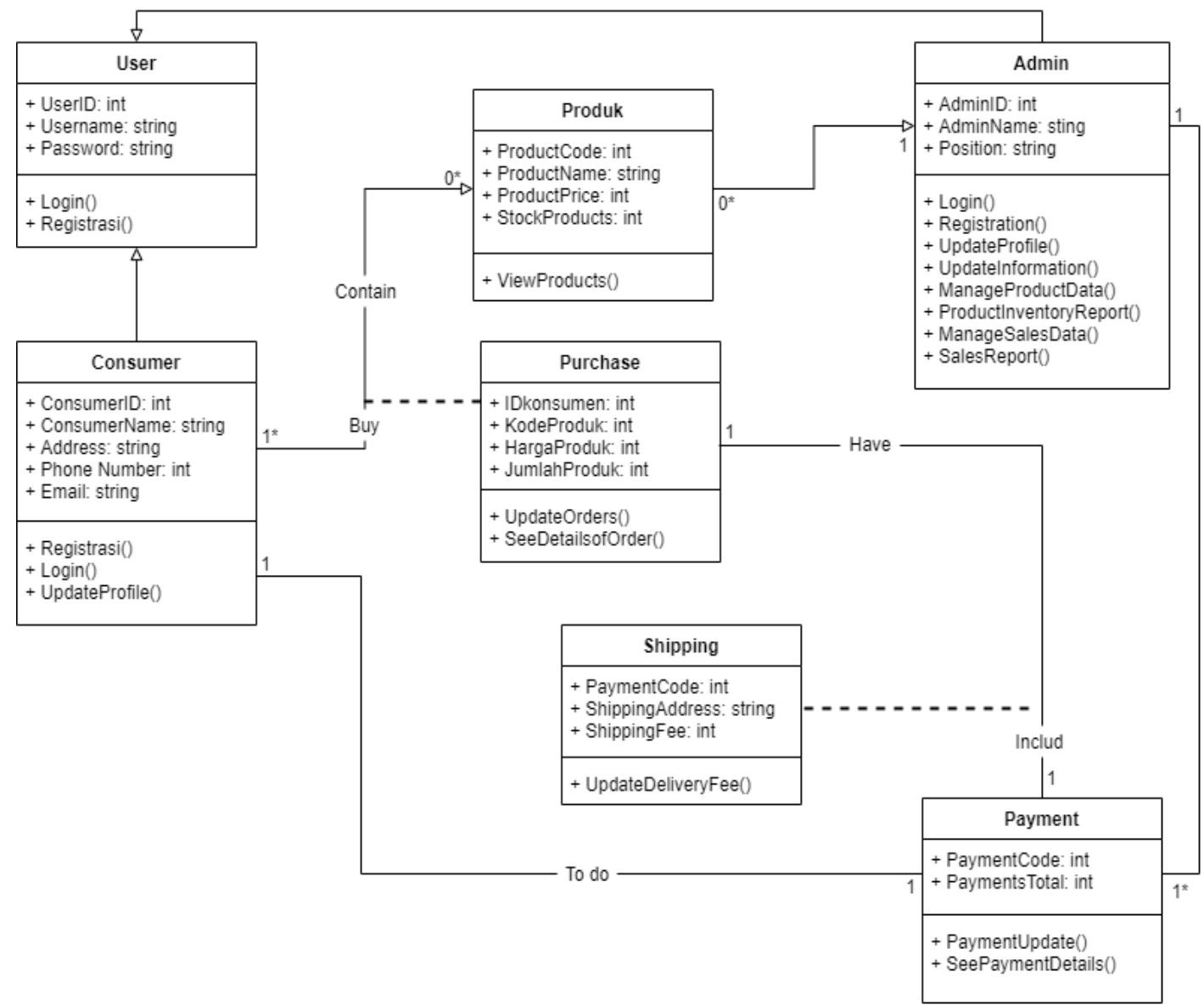

Picture 5. Class Diagram

Picture 5 is a diagram that explains the structure of the system by describing the definition of the class that will be used as a foundation in building the system. It also explains that there are 7 classes on the system that has been built, namely: Users, Costumers, Products, Purchases, Admins, Payments, and Shipping. 
JURNAL MEDIA INFORMATIKA BUDIDARMA

Volume 4, Nomor 3, Juli 2020, Page 683-692

ISSN 2614-5278 (media cetak), ISSN 2548-8368 (media online)

Available Online at https://ejurnal.stmik-budidarma.ac.id/index.php/mib

DOI 10.30865/mib.v4i3.2106

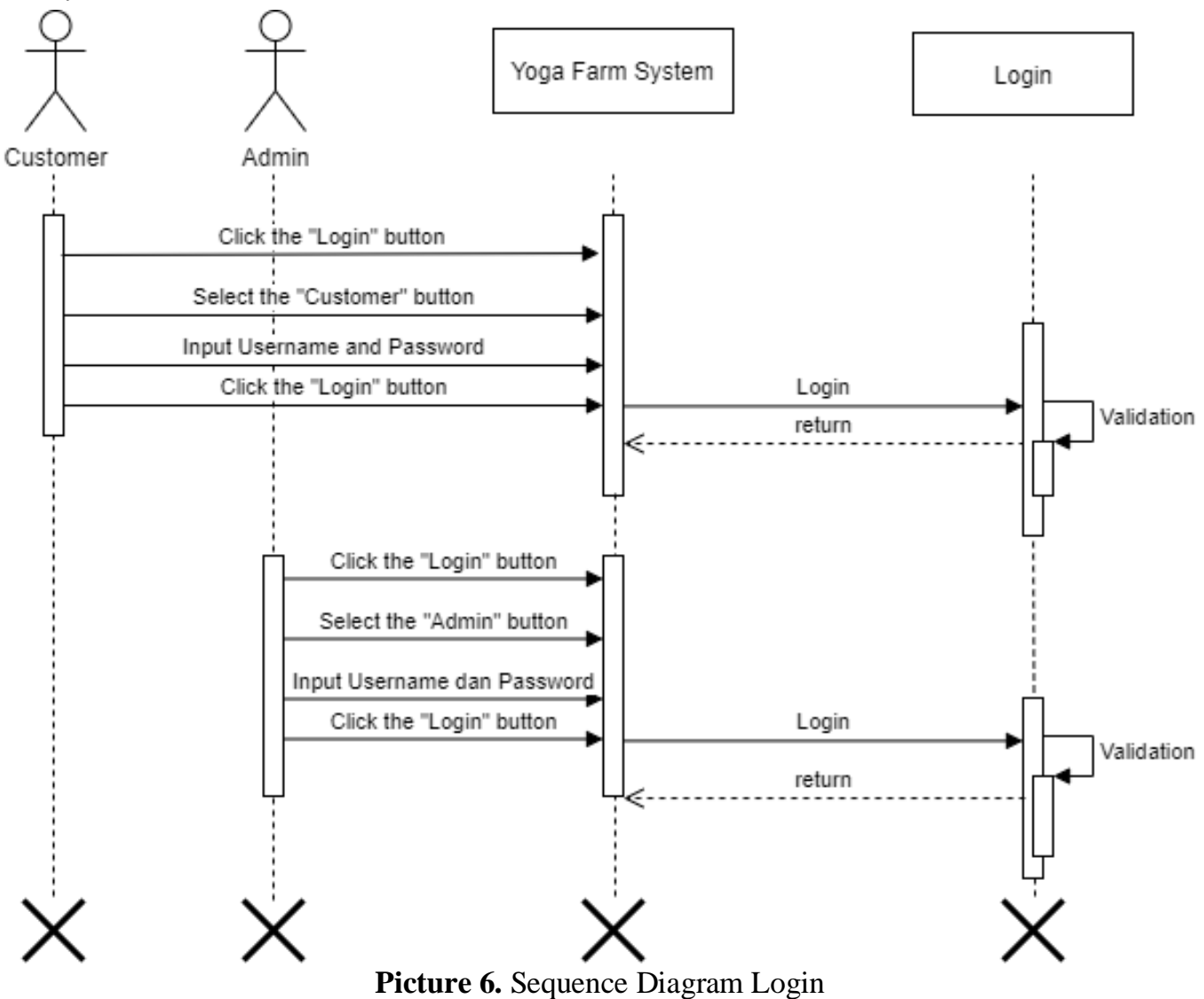

Picture 6 is a diagram that explains or illustrates the interaction of an object or actor with the system when logging into the system.

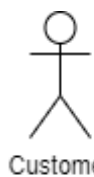

\section{Yoga Farm System}

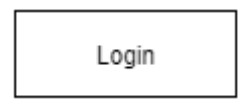

Buy Product

Customer

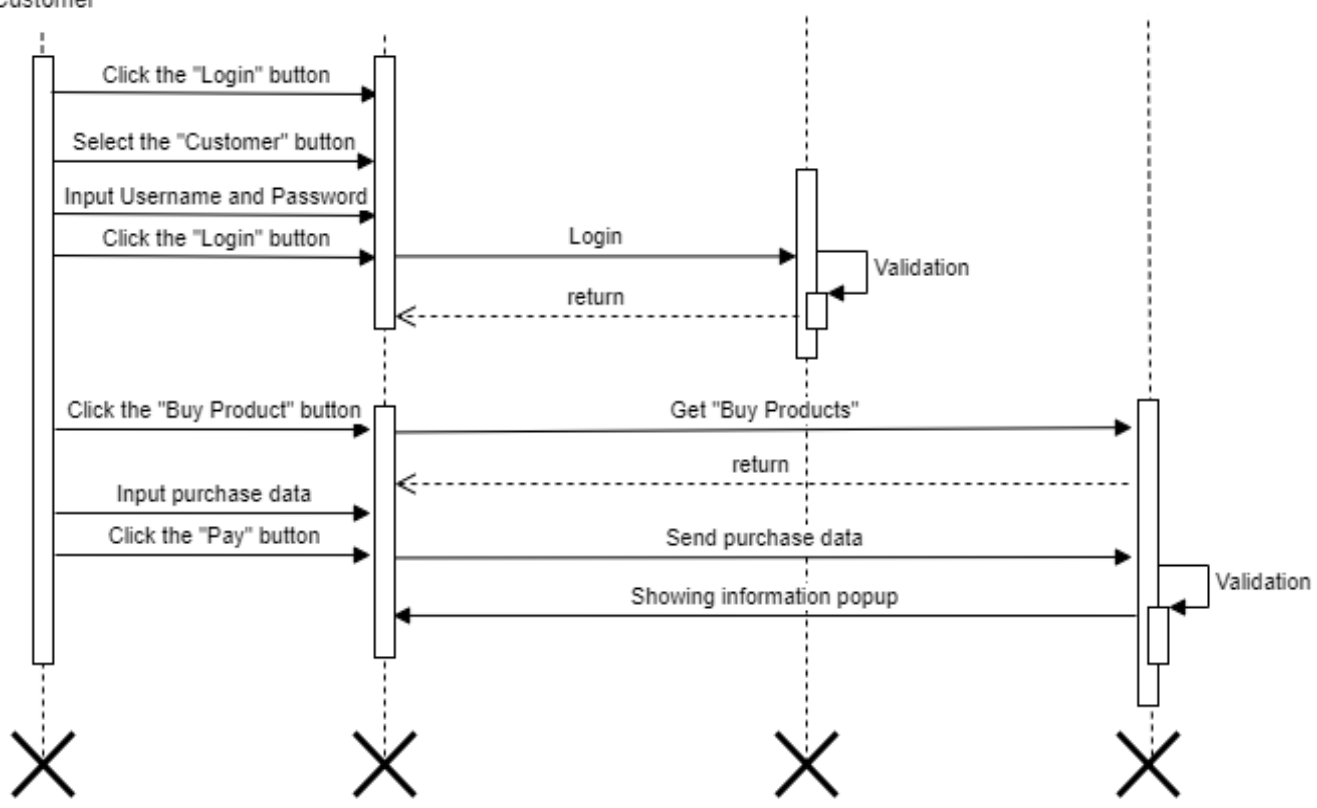

Picture 7. Sequence Diagram of Product Purchase

Picture 7 is a diagram that explains or illustrates the interaction of an object or actor with the system when purchasing products on the system 
JURNAL MEDIA INFORMATIKA BUDIDARMA

Volume 4, Nomor 3, Juli 2020, Page 683-692

ISSN 2614-5278 (media cetak), ISSN 2548-8368 (media online)

Available Online at https://ejurnal.stmik-budidarma.ac.id/index.php/mib

DOI 10.30865/mib.v4i3.2106

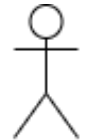

$$
\text { Yoga Farm System }
$$

Admin

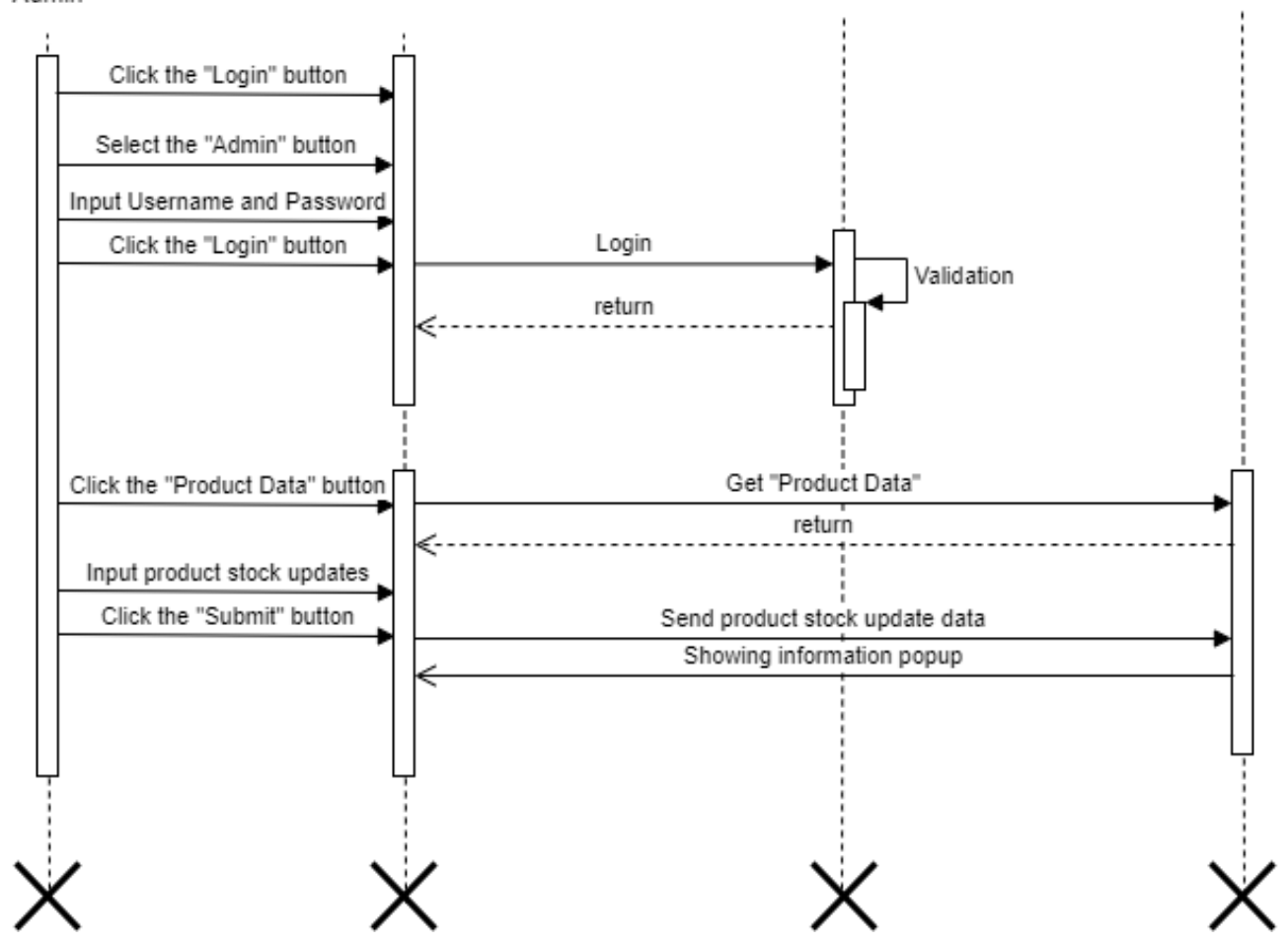

Picture 8. Sequence Diagram Manage Products

Picture 8 is a diagram that explains or illustrates the interaction of an object or actor with the system when managing or editing product data on the system.

\subsection{Design of User Interface}

In this section, there are two stages to be carried out, namely Creating a user interface design and testing a system design that was created. Making User Interface Design (UI) aims to display the appearance of applications made. In this study, the UI system design in web-based applications can help all users in understanding the design of the system being made.

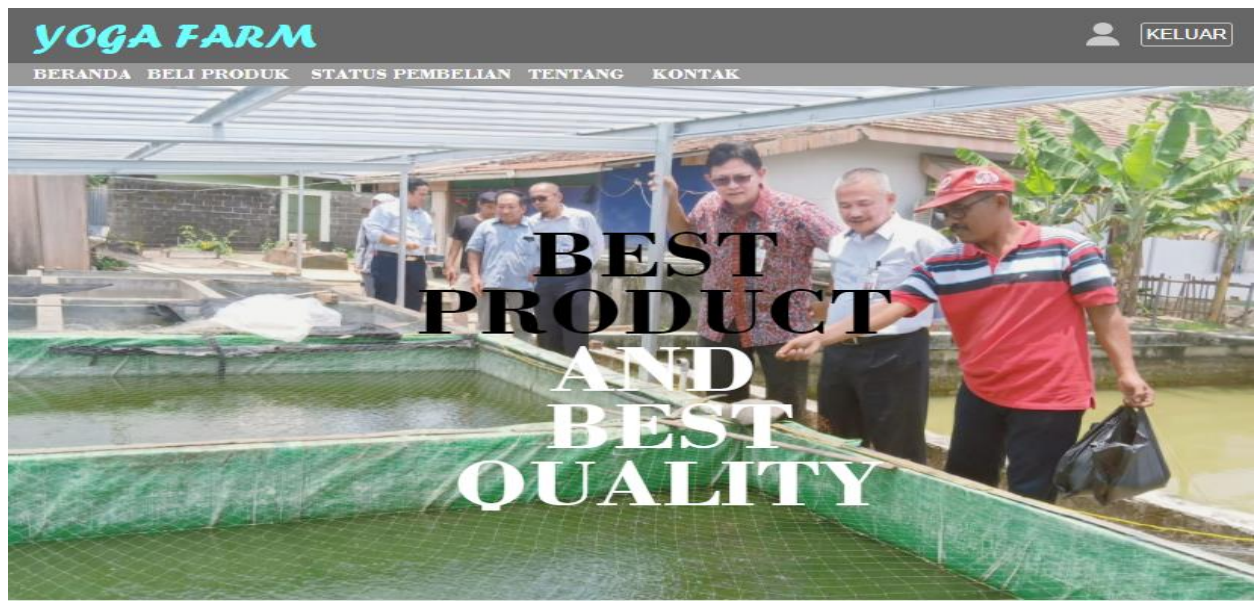

Picture 9. User Interface Homepage

Picture 9 shows the user interface design on the start page of the Yoga Farm System. On the home page, users are presented with a company slogan accompanied by photos of the location of Yoga Farm. 


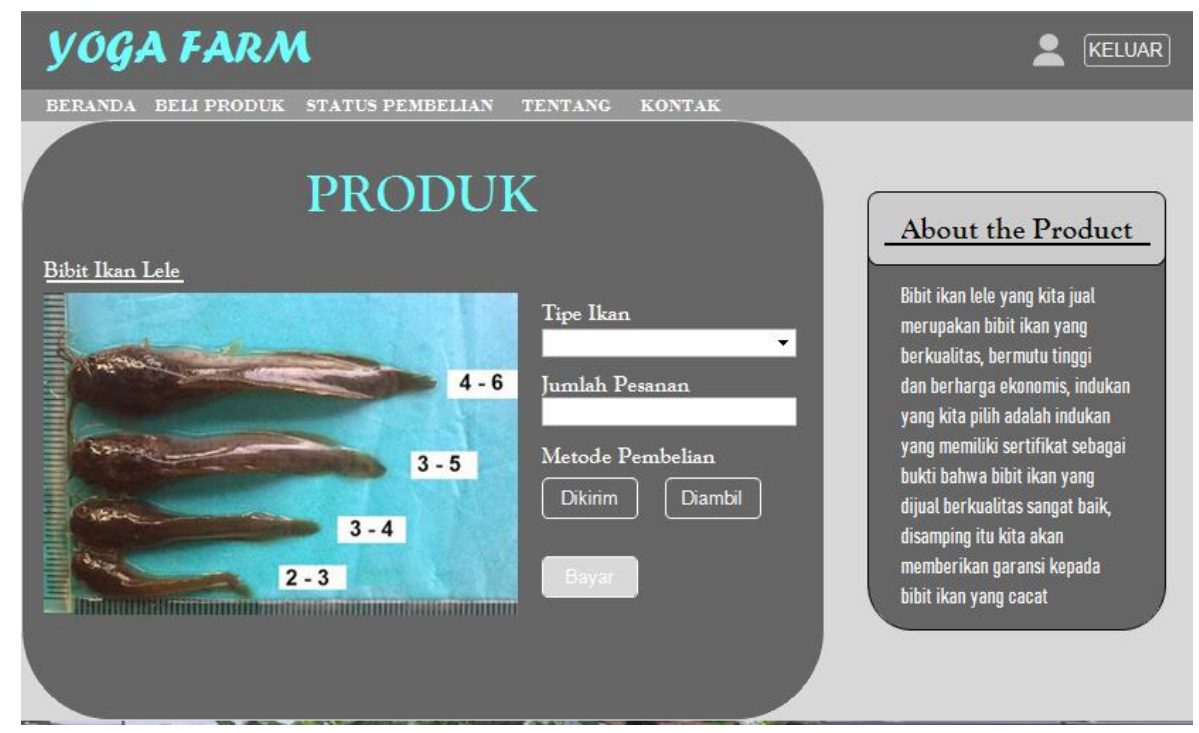

Picture 10. User Interface Product Purchase

Picture 10 shows the user interface design on the Product Purchase page after the users log in the system. On this page, the user is expected to fill in the purchase data completely.

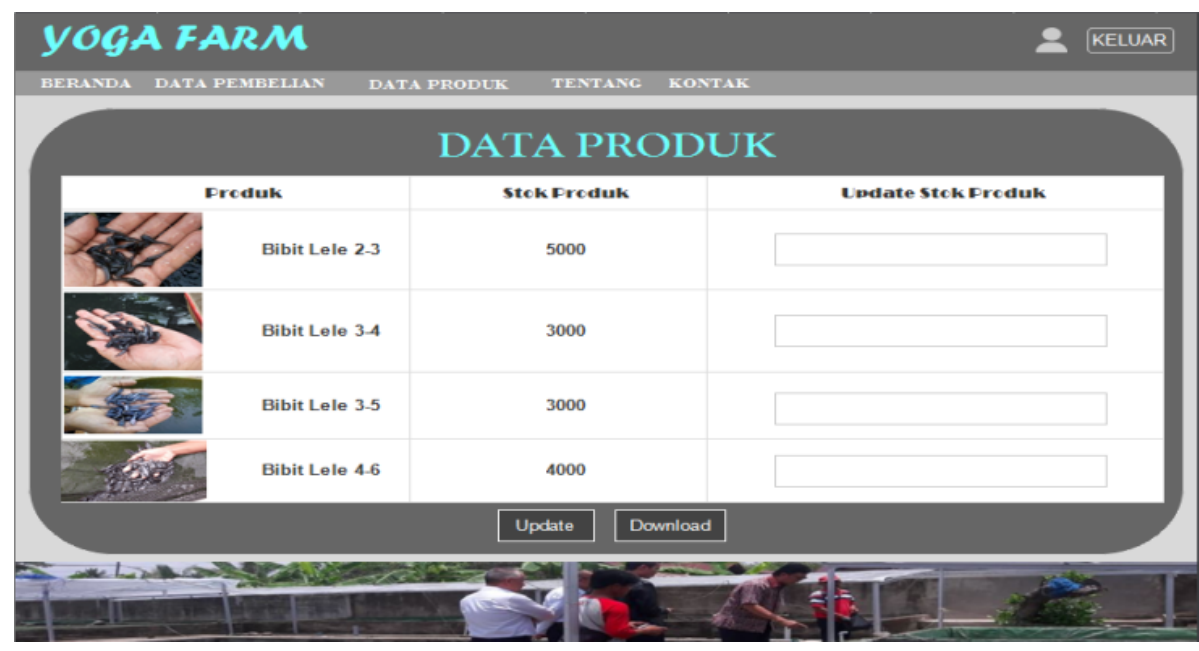

Picture 11. User Interface Manage Products

Picture 11 shows the user interface design on the Manage Product page. On this page, the user can see the amount of available stock, manage the amount of stock, and download the product inventory report.

\subsection{System Testing}

Information system design testing is conducted to find out whether a system that has been designed is in accordance with the user needs. In this study, the testing technique is conducted using informal review techniques by giving a few questions about the system that has been made. The questions are then given to prospective users and evaluated by researchers. Questions and answers from informal review techniques are presented in the following table:

Table 2. System Testing Results

\begin{tabular}{|c|c|c|c|c|c|}
\hline & \multirow[b]{2}{*}{ Question } & \multicolumn{4}{|c|}{ Interviewees } \\
\hline & & $\begin{array}{l}\text { Setia Budiman } \\
\text { (Owner) }\end{array}$ & $\begin{array}{l}\text { Tri Wahyu A. } \\
\text { S. (Manager) }\end{array}$ & $\begin{array}{l}\text { Abdurahman } \\
\text { (Employee) }\end{array}$ & $\begin{array}{c}\text { Udin } \\
\text { Iskandar } \\
\text { (Employee) }\end{array}$ \\
\hline 1 & $\begin{array}{l}\text { Is the User Interface display } \\
\text { consistent? }\end{array}$ & Yes & Yes & Yes & Yes \\
\hline \multirow[t]{2}{*}{2} & $\begin{array}{l}\text { Is the arrangement of the interest } \\
\text { hierarchy of the objects contained in } \\
\text { the application appropriate? }\end{array}$ & Yes & Yes & Yes & Yes \\
\hline & Question & \multicolumn{4}{|c|}{ Interviewees } \\
\hline
\end{tabular}


3 Does the application give the impression first or the appropriate characteristics in the first accessed?

4 Is the layout of the elements appropriate?

5 Is the typography used in the application appropriate?

6 Are the colors used correctly?

7 Is the use of images, icons etc. appropriate?

8 Is the application easy to understand?

Setia Budiman
(Owner)

Yes

Tri Wahyu A.

S. (Manager)

Abdurahman

(Employee)

Yes

Yes

Iskandar

(Employee)

Yes

\section{CONCLUSION}

A web-based sales system for Yoga Farm can help in disseminating information related to the product widely so that Yoga Farm costumers can increase. Increasing the number of costumers will certainly cause Yoga Farm income to increase. With the adoption of a web-based sales system, Yoga Farm can reduce the level of human error when making inventory reports and sales reports. While for costumers, a web-based sales system can make it easier to transact and get product-related information quickly. For further research, it is hoped that this research will become a reference for conducting similar research on other MSMEs or other businesses. If the system created for Yoga Farm is considered to have some shortcomings, researchers hope that the system can be improved and developed again.

\section{REFERENCES}

[1] J. Zheng, Y. Feng, and Y. Zhao, "A Unified Modeling Language-Based Design and Application for a Library Management Information System," Cybern. Inf. Technol., 2014.

[2] F. Rejaul Abedin, Ph.D., "Impact of Information Technology in Development of Global Businesses by 2030," Int. J. Inf. Technol., vol. 2, 2018.

[3] Yulianto et al., "ANALISA PERANAN TEKNOLOGI INTERNET SEBAGAI MEDIA TRANSAKSI E-COMMERCE DALAM MENINGKATKAN PERKEMBANGAN EKONOMI,” Semin. Nas. Teknol. Inf. dan Multimed. 2015, 2015.

[4] H. B. Dirgantara, "ANALISIS DAN PERANCANGAN APLIKASI E-COMMERCE BERBASIS WEB PADA CV DIMASINDO,” Semin. Nas. Teknol. Inf. dan Komun. 2016, 2016.

[5] APJII, Penetrasi dan Prilaku Pengguna Internet Indonesia 2017. Jakarta, 2017.

[6] Junadi and Sfenrianto, "A Model of Factors Influencing Consumer's Intention To Use E-Payment System in Indonesia," Procedia - Procedia Comput. Sci., vol. 59, pp. 214-220, 2015.

[7] A. G. Khan, "Electronic Commerce: A Study on Benefits and Challenges in an Emerging Economy," Glob. J. Manag. Bus. Res. B Econ. Commer., vol. 16, no. 1, 2016.

[8] KKPRI, Laporan tahunan 2017. Jakarta, 2017.

[9] KKPRI, Laporan Kinerja KKP 2018 (FINAL). Jakarta, 2018.

[10] B. W. Kesuma, Budiyanto, and B. Brata, "EFEKTIFITAS PEMBERIAN PROBIOTIK DALAM PAKAN TERHADAP KUALITAS AIR DAN LAJU PERTUMBUHAN PADA PEMELIHARAAN LELE SANGKURIANG (Clarias gariepinus) SISTEM TERPAL,” J. Penelit. Pengelolaan Sumberd. Alam dan Lingkung., vol. 8, 2019.

[11] M. H. F. Sitio, D. Jubaedah, and M. Syaifudin, "KELANGSUNGAN HIDUP DAN PERTUMBUHAN BENIH IKAN LELE (Clarias sp.) PADA SALINITAS MEDIA YANG BERBEDA,” J. Akuakultur Rawa Indones., vol. 5, 2017.

[12] P. D. M. Network, "Unit Usaha di Indonesia adalah UMKM?," Kumparan, 2020.

[13] R. Rahmidani, "Penggunaan E-Commerce Dalam Bisnis Sebagai Sumber Keunggulan Bersaing Perusahaan," Semin. Nas. Ekon. Manaj. DAN Akunt., 2015.

[14] A. Prasetyo and R. Susanti, "Sistem Informasi Penjualan Berbasis Web Pada PT. Cahaya Sejahtera Sentosa Blitar," J. Ilm. Teknol. dan Informasia ASIA, vol. 10, 2016.

[15] K. C. Laudon and J. P.Laudon, Sistem Informasi Manajemen Mengelola Perusahaan Digital. Yogyakarta, 2005.

[16] H. A. Mumtahana, S. Nita, and A. W. Tito, "Pemanfaatan Web E-Commerce untuk Meningkatkan Strategi Pemasaran," J. Ilmu Komput. dan Inform., vol. 3, 2017.

[17] S. M. Maulana, H. Susilo, and Riyadi, "IMPLEMENTASI E-COMMERCE SEBAGAI MEDIA PENJUALAN ONLINE (STUDI KASUS PADA TOKO PASTBRIK KOTA MALANG)," J. Adm. Bisnis, vol. 29, 2015.

[18] G. Urva and H. F. Siregar, "Pemodelan UML E-Marketing Minyak Goreng," J. Teknol. dan Sist. Inf., vol. 1, 2015.

[19] D. W. T. Putra and R. Andriani, "Unified Modelling Language (UML) dalam Perancangan Sistem Informasi Permohonan Pembayaran Restitusi SPPD," J. TEKNOIF, vol. 7, 2019.

[20] M. N. El Ghiffary, T. D. Susanto, and A. Herdiyanti, "Analisis Komponen Desain Layout, Warna, dan Kontrol Pada Antarmuka Pengguna Aplikasi Mobile Berdasarkan Kemudahan Penggunaan (Studi Kasus: Aplikasi Olride)," J. Tek. ITS, vol. 17, 2018 
JURNAL MEDIA INFORMATIKA BUDIDARMA

Volume 4, Nomor 3, Juli 2020, Page 683-692

ISSN 2614-5278 (media cetak), ISSN 2548-8368 (media online)

Available Online at https://ejurnal.stmik-budidarma.ac.id/index.php/mib

DOI 10.30865/mib.v4i3.2106

[21] A. Tarute, Shaharokh Nikoh, and R. Gatautis, "Mobile application driven consumer engagement," Telemat. Informatics, 2017.

[22] I. Sommerville, Software Engineering. Jakarta, 2011. 